\title{
Isolation from Klebsiella and Characterization of Two rcs Genes That Activate Colanic Acid Capsular Biosynthesis in Escherichia coli
}

\author{
By PHILIPPA ALLEN, ${ }^{1,2}$ C. A. HART ${ }^{2}$ AND J. R. SAUNDERS ${ }^{1 *}$ \\ Department of Microbiology ${ }^{1}$ and Medical Microbiology ${ }^{2}$, University of Liverpool, PO Box 147, \\ Liverpool L69 3BX, UK
}

(Received 23 June 1986; revised 29 September 1986)

\begin{abstract}
Two genes, designated $\operatorname{rcs} A$ (regulation of capsule synthesis) and $r c s B$, that had been cloned from the chromosome of Klebsiella aerogenes ( $K$. pneumoniae) capsular serotype K21 were capable of activating expression of colanic acid capsular polysaccharide in Escherichia coli K12. The Klebsiella $\operatorname{rcs} A$ gene encoded a polypeptide of $23 \mathrm{kDa}$ that was required for the induction of a mucoid phenotype at $\leqslant 30^{\circ} \mathrm{C}$ but not at $\geqslant 37^{\circ} \mathrm{C}$. The Klebsiella rcsB locus encoded no apparent polypeptides and was not capable by itself of causing the overproduction of colanic acid. However, when present in the same cell with $r \operatorname{cs} A$, either in cis or in trans, $r \operatorname{cs} B$ caused expression of mucoidy in $E$. coli at all growth temperatures. These findings are best explained if the Klebsiella rcs $A$ gene product acts as a positive regulator of colanic acid biosynthesis in E. coli and that activity of this protein is in turn subject to regulation by Lon protease. The Klebsiella rcs $B$ locus may exert its effect by preferentially binding a negative regulator of capsular biosynthesis, possibly Lon itself. DNA sequences homologous to the Klebsiella $\mathrm{K} 21 \mathrm{~b} r c s A$ and $\operatorname{rcs} B$ genes were found in the genomes of all other capsular serotypes of klebsiellae examined, including $\mathrm{K} 2, \mathrm{~K} 12$, $\mathrm{K} 36$ and K43. However, there was no homology between such genes and the chromosome of $E$. coli. The ability of these rcs genes to induce a mucoid phenotype explains the apparent conjugative transfer from klebsiellae to $E$. coli of the ability to produce $\mathrm{K} 21$ or other Klebsiella capsular polysaccharides that are structurally and antigenically related to colanic acid.
\end{abstract}

\section{INTRODUCTION}

Klebsiellae are important nosocomial pathogens (Meers et al., 1981) and can cause lifethreatening bacteraemia in adults (de la Torre et al., 1985) and in neonates (Morgan et al., 1984). Characteristically Klebsiella species are surrounded by a hydrophilic polysaccharide capsule and at least 83 different capsular serotypes have been recognized (Nimmich, 1968). It has been reported that the ability to express a sero-specific capsular antigen can be transferred from some strains of $K$. aerogenes (K. pneumoniae) $\mathrm{K} 21$ to Escherichia coli K12 (Barr, 1981). Attempts in this laboratory to transfer the ability to elicit either a mucoid character or K21 antigen per se by conjugation to $E$. coli or other klebsiellae have proved unsuccessful. However, it has proved possible to transfer genes responsible for the expression of a mucoid phenotype by conjugation from a K36-producing strain of $K$. aerogenes to $E$. coli $\mathrm{K} 12$ (unpublished observations).

$E$. coli $\mathrm{K} 12$ is non-mucoid under normal laboratory conditions but some mutant strains are capable of synthesizing large amounts of the capsular polysaccharide colanic acid under certain conditions (Markovitz, 1977). Mutations at a number of loci, including the lon gene, result in copious synthesis of colanic acid and hence confer a mucoid phenotype. The lon gene of $E$. coli codes for a tetrameric protein with subunits of $94 \mathrm{kDa}$ (Schoemaker \& Markovitz, 1981). This protein exhibits multiple enzymic activities and probably acts as a repressor of the enzymes involved in colanic acid synthesis (Trisler \& Gottesman, 1984).

Abbreviations: CIE, countercurrent immunoelectrophoresis; MMS, methyl methanesulphonate. 
Colanic acid cross-reacts strongly with a number of Klebsiella antigens including the K21 polysaccharide (Henriksen, 1954). The Klebsiella K21 serotype does not form a homogeneous population but consists of strains producing one or other of two chemically distinct types of capsular polysaccharide which we have referred to as $\mathrm{K} 21$ a for capsules with the structure reported by Choy \& Dutton (1973) and a novel type referred to as K21b (unpublished observations). During an investigation of the genetic regulation of the production of K21b-type capsular polysaccharide we noted that some Klebsiella DNA fragments can activate colanic acid synthesis in E. coli $\mathrm{K} 12$. This paper describes the isolation and characterization of two Klebsiella rcs (regulation of capsule synthesis) genes capable of producing this response.

\section{METHODS}

Bacterial strains and plasmids. Klebsiella aerogenes strain U53/1 (redesignated 1L918) and an E. coli transconjugant, designated 1L920, were obtained from J. G. Barr, Victoria Hospital, Belfast, N. Ireland (Barr, 1981). Other Klebsiella strains were clinical isolates obtained from the Royal Liverpool Hospital. E. coli DH1 $\left(\right.$ recA, hsd $\mathrm{r}_{\mathrm{k}}{ }^{-}, \mathrm{m}_{\mathrm{k}}{ }^{+}$) (Hanahan, 1983) was used as the recipient in cloning experiments. E. coli $\mathrm{C} 600$ (rec $\left.A^{+}\right)$ (Appleyard, 1954) was used in methyl methanesulphonate (MMS) sensitivity experiments. Plasmids pLV59 (O'Connor \& Humphreys, 1982), pBR322 (Bolivar et al., 1977) and pLG339 (Stoker et al., 1982) were used as cloning vectors.

Isolation of DNA. Chromosomal DNA was prepared according to the method of Marmur (1961). Plasmid DNA was isolated by the bulk preparation method of Humphreys et al. (1975).

Restriction enzyme digestion and ligation of DNA. Restriction enzymes (obtained from $\mathrm{P}$ and $\mathrm{S}$ Biochemicals, Liverpool, or from Boehringer) were used according to the supplier's recommendations. DNA fragments were typically ligated at a concentration of $100 \mu \mathrm{g} \mathrm{ml}^{-1}$ at $16^{\circ} \mathrm{C}$ overnight; $0.2 \mathrm{U}$ of T4 DNA ligase was added for each $\mu \mathrm{g}$ of DNA.

Agarose gel electrophoresis. DNA samples were run on horizontal agarose slab gels containing ethidium bromide in Tris/borate buffer ( $89 \mathrm{mM}$-Tris, $89 \mathrm{~mm}$-boric acid, $2 \mathrm{mM}$-EDTA). DNA samples were mixed with loading buffer [ $50 \mathrm{mM}$-EDTA, $4 \mathrm{M}$-urea, $8 \%$ (w/v) Ficoll, $0 \cdot 1 \%(\mathrm{w} / \mathrm{v})$ bromophenol blue] and gels were run at $100 \mathrm{~V}$ for several hours or $20 \mathrm{~V}$ overnight. DNA was visualized using a $302 \mathrm{~nm}$ transilluminator.

Transformation. Transformation of $\mathrm{CaCl}_{2}$-treated $E$. coli and Klebsiella with plasmid DNA was by the method of Saunders et al. (1984).

Hybridization of DNA. DNA from agarose gels was transferred to nitrocellulose filters according to the method of Southern (1975). Probe DNA $(1 \mu \mathrm{g})$ was labelled with $\left[\alpha-{ }^{35}\right.$ S $] \mathrm{dATP}(10 \mu \mathrm{Ci}, 370 \mathrm{kBq})$ by nick translation with DNA polymerase I. The filter-bound DNA was hybridized overnight at $65^{\circ} \mathrm{C}$ with $2 \times \operatorname{SSC}(0.3 \mathrm{M}-\mathrm{NaCl}, 0.03 \mathrm{M}-$ trisodium citrate), $0.3 \%$ (w/v) sodium dodecyl sulphate (SDS), $100 \mu \mathrm{g}$ denatured calf thymus DNA and $1 \mu \mathrm{g}$ denatured probe DNA. The filter was then washed at $65^{\circ} \mathrm{C}$ in $2 \times$ SSC containing $1 \%(w / v)$ SDS, dried and exposed to X-ray film overnight.

$M M S$ sensitivity. Strains were grown in LB overnight and then appropriately diluted before spreading on LB agar plates and LB-MMS plates (containing 0.05\%, v/v, MMS). Plates were incubated overnight and colony counts were subsequently performed.

Capsular serotyping. This was done by using counter-current immunoelectrophoresis (CIE) as described by Palfreyman (1978) and by immunofluorescence. Strains were also serotyped independently by the Coventry Public Health Laboratory using CIE and Quellung reactions as described by Casewell (1972).

Polysaccharide extraction. Exopolysaccharide was extracted from mucoid strains according to the method of Wilkinson et al. (1955). Bacteria were grown on a minimal medium consisting of $0.4 \mathrm{~g} \mathrm{NH}_{4} \mathrm{Cl}, 7.5 \mathrm{~g} \mathrm{Na}_{2} \mathrm{HPO}_{4}$, $3.0 \mathrm{~g} \mathrm{KH}_{2} \mathrm{PO}_{4}, 0.5 \mathrm{~g} \mathrm{NaCl}, 0.2 \mathrm{~g} \mathrm{Mg}_{2} \mathrm{SO}_{4} .7 \mathrm{H}_{2} \mathrm{O}, 0.01 \mathrm{~g} \mathrm{CaCl}_{2} .2 \mathrm{H}_{2} \mathrm{O}$ and $10 \mathrm{~g}$ agar in 11 distilled water. The cells were then harvested and resuspended in distilled water. The capsules were removed from the cells by boiling for $10 \mathrm{~min}$ and the suspension was centrifuged for $30 \mathrm{~min}$ at $20000 \mathrm{~g}$. The supernatant was retained and the capsular polysaccharide was precipitated with 2 vols acetone. The polysaccharide was resuspended to form a $0.5 \%(\mathrm{w} / \mathrm{v})$ solution in acetate buffer $[4 \%(\mathrm{w} / \mathrm{v})$ sodium acetate, $2 \%(\mathrm{w} / \mathrm{v})$ acetic acid $]$ and was then deproteinized by shaking $100 \mathrm{ml}$ volumes with $20 \mathrm{ml}$ chloroform and $4 \mathrm{ml}$ butanol. The polysaccharide was then reprecipitated with 2 vols acetone, dialysed extensively against tap water, precipitated and freeze dried. Purified polysaccharide $(5 \mathrm{ml})$ was hydrolysed in $1 \mathrm{ml} \mathrm{HCl}(2 \mathrm{M})$ for $3 \mathrm{~h}$ at $100^{\circ} \mathrm{C}$, rotary evaporated and resuspended in $20 \mu \mathrm{l}$ distilled water. The hydrolysates were applied to Whatman $3 \mathrm{MM}$ chromatography paper and run in butanol/acetic acid/water $(4: 1: 5$, by vol.) solvent. The papers were developed were developed with alkaline silver nitrate to allow detection of the sugars.

Isolation and labelling of minicells. Minicells were isolated from E. coli DS410 and its plasmid-bearing derivatives essentially by the method of Halliwell \& Sherratt (1976). Minicells were purified on sucrose gradients and 
resuspended in minicell labelling medium containing $0.01 \%(w / v)$ methionine assay medium, $1 \%(w / v)$ glucose and M9 minimal salts solution. Minicells $\left(2 \times 10^{8}\right)$ were preincubated before the addition of $\left[{ }^{35} S\right]$ methionine $(30 \mu \mathrm{Ci}, 1 \cdot 1 \mathrm{MBq})$ and further incubated for $60 \mathrm{~min}$. After labelling, the minicells were washed and resuspended in final sample buffer $[10 \%(\mathrm{w} / \mathrm{v})$ glycerol, $5 \%$ (v/v) 2-mercaptoethanol, 3\% (w/v) SDS, $0.0625 \mathrm{M}-\mathrm{Tris}, 0.01 \%$ (w/v) bromophenol blue $\mathrm{pH}$ 6.8].The sample was then boiled and analysed by SDS-PAGE.

$S D S-P A G E$. SDS-PAGE of proteins was done on $10-17 \%(\mathrm{w} / \mathrm{v})$ gradient vertical slab gels according to the method of Laemmli (1970). The gels were run typically with a current of $10 \mathrm{~mA}$ for $1 \mathrm{~h}$ and then at a constant current of $20 \mathrm{~mA}$ until the tracking dye reached the bottom of the gel. The gel was stained with Coomassie blue, dried down on to Whatman $3 \mathrm{MM}$ paper and exposed to X-ray film.

DNA sequencing. Cloned DNA was cut in single or double digestions with a number of restriction enzymes and was then ligated to appropriately cleaved M13 mp8 or mp9 DNA (Messing \& Vieira, 1982). Ligation mixtures were transfected into $\mathrm{CaCl}_{2}$-treated $E$. coli JM103 cells. M13 recombinants were identified as white plaques on plates containing X-gal and IPTG. Preparation of single-stranded template and sequencing reactions have been described elsewhere (Walker et al., 1986). Samples were boiled for $3 \mathrm{~min}$ before loading on polyacrylamide gels $(6 \%, w / v)$. The gels were typically run at $30 \mathrm{~mA}$ until the tracking dye reached the bottom of the gel. The gel was fixed, washed and then dried at $80^{\circ} \mathrm{C}$ for $60 \mathrm{~min}$. The dehydrated gel was then exposed to X-ray film overnight. The entire sequence of the cloned DNA was determined by sequencing a series of overlapping M13 mp8 or mp9 subclones.

\section{RESULTS}

\section{Cloning of Klebsiella DNA in pLV59}

The plasmid pLV59 (O'Connor \& Humphreys, 1982) is a derivative of pACYC184 that carries a chloramphenicol-resistance determinant and the EcoRI restriction/modification genes. The EcoRI methylase gene carried by this plasmid is temperature sensitive, being functional at $28^{\circ} \mathrm{C}$ but not at $37^{\circ} \mathrm{C}$. Hence, the vector is lethal to its host at $37^{\circ} \mathrm{C}$ and above. Cloning of a DNA fragment into the BglII site inactivates the EcoRI restriction gene and permits cells containing the hybrid plasmid to survive at $37^{\circ} \mathrm{C}$. Partial Sau3A digests of total Klebsiella K21b (1L918) DNA were cloned into the BgIII site of pLV59 and the ligation mixture was used to transform $E$. coli $\mathrm{DH} 1$. Two recombinant clones were isolated that conferred a mucoid phenotype on $E$. coli grown at $37^{\circ} \mathrm{C}$. The clones possessed recombinant plasmids with DNA inserts of $14 \mathrm{~kb}$ (pLV210) and $11.5 \mathrm{~kb}$ (pLV211) respectively. Restriction analysis of plasmid DNA indicated that a $9 \mathrm{~kb}$ region of inserted DNA was shared by both pLV210 and pLV211. Subcloning of BglII/BamHI fragments of pLV210 into pLV59 localized the Klebsiella genes responsible for the mucoid phenotype to a $2.7 \mathrm{~kb}$ segment. The recombinant plasmid carrying this fragment was designated pLV212. In addition, subcloning of partial Sau3A digests of pLV210 into pLV59 allowed the isolation of clones that possessed a mucoid phenotype when grown at $\leqslant 30^{\circ} \mathrm{C}$ but not at $37^{\circ} \mathrm{C}$. These clones were found to contain identical species of plasmid DNA with an insert size of $1.2 \mathrm{~kb}$. One of these clones was designated pLV213. Sau $3 \mathrm{~A}$ digests of pLV210 DNA were also cloned into pBR322, which is compatible with pLV59. Recombinants were transformed into cells containing pLV213 and selection was made for clones that expressed the mucoid phenotype at all growth temperatures. Plasmid DNA was extracted from mucoid strains and pBR322 recombinant plasmids were isolated. Restriction analysis of the plasmid DNA identified two types of pBR322 recombinant clones, containing inserts of $1.2 \mathrm{~kb}$ (pLV214) and $0.39 \mathrm{~kb}$ (pLV215). The insert DNA of pLV214 was identical to that of pLV213 and E. coli cells containing pLV214 possessed a mucoid phenotype when grown at $\leqslant 30^{\circ} \mathrm{C}$ but not at $37^{\circ} \mathrm{C}$. However, the restriction map of the insert DNA of pLV215 differed from that of pLV213 and E. coli cells containing pLV215 alone did not exhibit the mucoid phenotype at any growth temperature. The restriction maps of these plasmids are shown in Fig. 1. Insert DNA from pLV213 was also cloned into the low-copy-number (6-8 copies per chromosome) plasmid vector pLG339. The resulting recombinants also expressed the mucoid phenotype when grown at $\leqslant 30^{\circ} \mathrm{C}$ but not at $37^{\circ} \mathrm{C}$. pLV213 when transformed into $K$. aerogenes 1L919, a non-mucoid derivative of the K21b strain 1L918, failed to induce biosynthesis of colanic acid. 


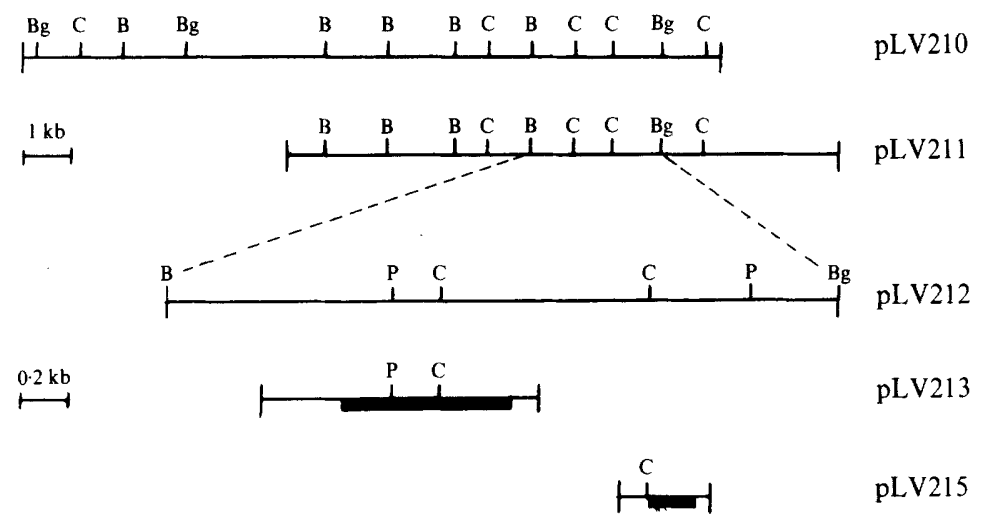

Fig. 1. Restriction maps of Klebsiella DNA capable of inducing a mucoid phenotype in $E$. coli. The boxed areas refer to the putative coding regions of $r \operatorname{cs} A$ (pLV213) and $r c s B$ (pLV215) deduced from the primary DNA sequence. B, Bam HI; Bg, BglII; C, ClaI; P, Pst I.

Table 1. Capsular serotyping of clones using CIE, Quellung reaction and immunofluorescence

\begin{tabular}{|c|c|c|c|}
\hline \multirow[b]{2}{*}{ Strain } & \multicolumn{3}{|c|}{ Reactions* } \\
\hline & CIE & Quellung & $\begin{array}{l}\text { Immuno- } \\
\text { fluorescence }\end{array}$ \\
\hline K. aerogenes $1 \mathrm{~L} 918$ & K21 & $\mathrm{K} 21$ & $\mathbf{K} 21$ \\
\hline E. coli $\mathrm{DH} 1(\mathrm{pLV} 210)$ & NT & K21 & K21 \\
\hline E. coli DH1(pLV211) & NT & $\mathrm{K} 21$ & K21 \\
\hline E. coli $\mathrm{DH} 1(\mathrm{pLV} 213)$ & NT & $\mathrm{K} 21$ & K21 \\
\hline E. coli DH1(pLV59) & NT & NT & NT \\
\hline
\end{tabular}

NT, not typable.

* Results were identical when the tests were repeated on two separate occasions.

\section{Serotyping of mucoid clones}

Capsular serotyping indicated that the $E$. coli clones elicited K21-specific material by immunofluorescence but not by CIE (Table 1). In independent tests by the Coventry Public Health Laboratory the clones were shown to exhibit K21 serospecificity with Quellung reactions but not with CIE. These clones have also been tested with antisera raised against the E. coli $\mathbf{M}$ antigen and found to react both with Klebsiella K21 and E. coli $\mathrm{M}$ (colanic acid) antisera (F. Ørskov \& I. Ørskov, personal communication).

\section{Examination of capsular polysaccharide extracted from mucoid clones}

Capsular polysaccharide was extracted from $K$. aerogenes $1 \mathrm{L918}$ and mucoid $E$. coli clones to determine whether the recombinants were producing K21 antigen or colanic acid. Purified polysaccharide was hydrolysed and examined by paper chromatography. The capsular polysaccharide of the mucoid $E$. coli clones contained glucuronic acid, galactose, glucose and fucose in accordance with the reported structure for colanic acid (Garegg et al., 1971) rather than K21b polysaccharide, which contains glucuronic acid, galactose and rhamnose (unpublished observations). In addition, the mucoid transconjugant reported by Barr (1981) to have received $\mathrm{K} 21$-specific genes appeared to produce colanic acid rather than $\mathrm{K} 2 \mathrm{l} \mathrm{b}$ capsular polysaccharide.

\section{$M M S$ sensitivity of mucoid clones}

lon mutants produce altered Lon protease with a decreased ability to carry out in vitro ATPdependent proteolysis (Chung et al., 1983). lon mutants also exhibit several other phenotypic characteristics, including sensitivity to DNA damage (Howard-Flanders et al., 1964) and decreased lysogenization by phage $\lambda$ (Walker et al., 1973). To determine whether the $E$. coli 


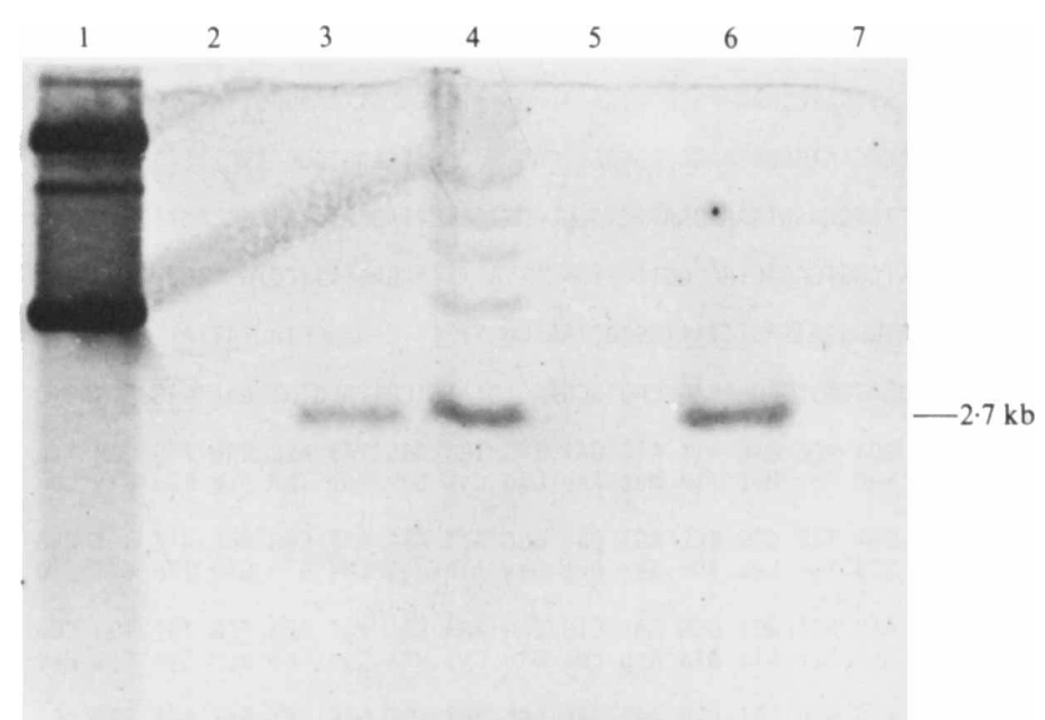

Fig. 2. Southern transfer hybridizations of DNA cleaved with $B g l I I$ and BamHI from klebsiellae and mucoid $E$. coli derivatives using pLV213 DNA as a probe. Tracks: (1) pLV213, (2) plasmid DNA extracted from Klebsiella K21b 1 L918, (3) 1 L918 chromosomal DNA, (4) total DNA from Klebsiella IL919, (5) total DNA from $E$. coli transconjugant 1L920, (6) total DNA from $K$. aerogenes K36 1L884, (7) total DNA from $E$. coli $\mathrm{DH} 1$. In track 4 , bands of homology additional to the $2.7 \mathrm{~kb}$ fragment are attributable to partial digestion of $K$. aerogenes 1L919 DNA.

clones carrying Klebsiella DNA were mucoid due to the generation of a Lon- phenotype, the clones were tested for MMS sensitivity. lon mutants are unable to induce the SOS repair system and are thus sensitive to the SOS-inducing agent MMS. pLV213 and pLV212 were transformed into $E$. coli $\mathrm{C} 600$, which is $r e c A^{+}$and thus competent to repair DNA damage. Strains carrying either recombinant plasmid were MMS-resistant. Furthermore, carriage of these plasmids did not render the host cells liable to filamentation following UV-irradiation nor reduce plaquing efficiency of $\lambda$ phage (data not shown). Thus neither of these cloned segments of the $K$. aerogenes chromosome renders $E$. coli Lon $^{-}$.

\section{Hybridization of cloned DNA}

To determine the location of the cloned 1L918 genes, plasmid and chromosomal DNA preparations isolated from $K$. aerogenes 1L918 were probed with labelled insert DNA from pLV213. Chromosomal DNA preparations isolated from 1 L919 (a spontaneous non-mucoid derivative of the $\mathrm{K} 21 \mathrm{~b}$ strain), the $K$. aerogenes $\mathrm{K} 36$ strain $1 \mathrm{L884}$, the mucoid $E$. coli transconjugant (1L920) and E. coli K12 (DH1) were also included. The hybridization data shown in Fig. 2 demonstrate that the cloned mucoidy genes from $1 \mathrm{~L} 918$ are located on a $2.7 \mathrm{~kb}$ $B g l$ II-BamHI fragment of chromosomal DNA rather than on plasmid DNA. The results also indicate the presence of these genes in the non-mucoid Klebsiella derivative and in the K36 $K l e b s i e l l a$ strain. However, the genes appeared absent in the $E$. coli transconjugant and in $E$. coli K12. DNA homologous to the cloned DNA from pLV213 was also present in Klebsiella serotypes K2, K12 and K43 (data not shown).

\section{DNA sequencing of $p L V 213$ and $p L V 215$}

The sequence of the $1.2 \mathrm{~kb}$ insert of pLV213 was determined by the dideoxy chain termination method using overlapping subfragments subcloned in M13 mp8 and mp9. The sequence of the cloned DNA in pLV213 is shown in Fig. 3. Only one open reading frame of 1165 nucleotides with recognizable transcription initiation and termination sites was evident. The sequence of the $0.39 \mathrm{~kb}$ insert of pLV215 was also determined and contained one possible short coding region apparently of $220 \mathrm{bp}$ (Fig. 4). 
1 GATCAACCTGTACGCAACCGGCCAGCGCCACCACCATGCCAGCAAAAAATAACTTITT

59 CATCATTCATCCCACAAGCCGATAAAAAAGTATTGTGGCATTAAAGCGTTAAGCCTTCCACCC

122 CCACCGCAAAGGGATAAGCGAGCAAGCCAGCAACCGCTAACGTGGGTTTCATTTGAAGTAAGG

185 AAATTCTGAAAGTAAAAGAATACTGGGCGCGTAACCATAGCATCTATGGGCACTTTTTGTTTT

248 TAATTCGGTCACACTACCGGTTCTTGACTTTACTITAAGAGTTTTCCTGGCAAATIATATGCA

311 TAGATGCGGAATAGITTAATGGAGCTAATGGGTTCTITCTAAACCTACTATTATTATCGCCCG

374 CAAGGACTGCTTCGCACAGCCAGTGCGAAGTGTATATCGTTACGTGTTGATTGAGGATGGGTC

437 ATG TCA ACG ATG ATT ATG GAT TTG TGC AGC TAT ACC CGG TTG GGA TTG Met Ser Thr Met Ile Met Asp Leu Cys Ser Tyr Thr Arg Leu Gly Leu

485 ACG GGA TAT CTG ACC AGT CGG GGA ATT AAA AAA CAG GAA ATC GTT GAG Thr Gly Tyr Leu Thr Ser Arg Gly Ile Lys Lys Gln Glu Ile Val Glu

533 GTC AAC AGT GCT GCG GAT CTG CAG AAA CAC TGT ACG TCG TGT TGC CCG Val Asn Ser Ala Ala Asp Leu Gln Lys His Cys Thr Ser Cys Cys Pro

581 GCG GTG GTG TTT CTG AAT GAA GAC TGT ITC GTG CAT GAT GAT GAA AGT Ala Val Val Phe Leu Asn Glu Asp Cys Phe Val His Asp Asp Glu Ser

629 AAT GGC ATT ATT CGC CAG ATC ATT ACG CAA AAC CCG GCG ACG CTG TTT Asn Gly Ile Ile Arg Gln Ile Ile Thr Gln Asn Pro Ala Thr Leu Phe

677 GTT ATC TTT ATG TCG CTG GCG AAC ATC CAT TTT GAC CGC TAT TTG CGG Val Ile Phe Met Ser Leu Ala Asn Ile His Phe Asp Arg Tyr Leu Arg

725 GTA CGG AAG AAT CTG CTA ATC AGT TCA AAA TCG ATA ACC CCA AAA GAC Val Arg Lys Asn Leu Leu Ile Ser Ser Lys Ser Ile Thr Pro Lys Asp

773 CTT GAT GTT ATT CTG GTT AAT TAT CTT AAA TAC AAA AAC ACC AGT GTA Leu Asp Val Ile Leu Val Asn Tyr Leu Lys Tyr Lys Asn Thr Ser Val

821 GGC CAG TTA ACT TTA CCG ACA TTG TCA CTG AGT AAA ACA GAA TCA AAT Gly Gln Leu Thr Leu Pro Thr Leu Ser Leu Ser Lys Thr Glu Ser Asn

869 ATG CTG CAA ATG TGG ATG GCC GGG CAT GGT ACT TCG CAA ATC TCA ACG Met Leu Gln Met Trp Met Ala Gly His Gly Thr Ser Gln Ile Ser Thr

917 CAA ATG AAC ATC AAA GCG AAG ACG GTA TCG TCG CAT AAA GGC AAT ATT Gin Met Asn Ile Lys Ala Lys Thr Val Ser Ser His Lys Giy Asn Ile

965 AAA AAG AAA ATA CAA ACG CAT AAT AAG CAG GTG ATT TAT CAT ATC GTT Lys Lys Lys Ile Gin Thr His Asn Lys Gln Val Ile Tyr His Ile Val

1013 CGG CTG ACC GAA AAC ATC ACC TCC GGT ATT CAG GTA AAT ATG CGC TGA Arg Leu Thr Glu Asn Ile Thr Ser Giy Ile Gin Val Asn Met Arg

1061 AACAAACTGGCGGCGCTCCCGCCAGTTCAGTTTTACGAGACCTCTTTTTCCACGAAAATCCCA

1124 TCCGGGTGGCCTATTICATTAAAAAACCAGATC

Fig. 3. Nucleotide sequence of the region containing the rcs gene carried by pLV213 and the predicted amino acid sequence of the $r \operatorname{cs} A$ protein. The suggested Shine-Dalgarno sequence is boxed and sequences sharing homology with the $E$. coli consensus -10 promoter sequence are underlined. A classical $E$. coli -35 promoter region was not apparent.

\section{Insertional inactivation of plasmid DNA}

The cloned rcs gene represented by the 1165 bp open reading frame specified by pLV213 was inactivated by the in vitro insertion of $C l a I$ fragments of $\lambda$ DNA into the single ClaI site present within the putative coding region. The resulting ligation mixture was transformed into $E$. coli $\mathrm{K} 12$ and plasmid DNA was extracted from clones that possessed a non-mucoid phenotype at 


\section{ATTCTCAAIATTTTGCGTCATGAATATCTCTTGTCATGCAAAATAATTGAGGATA}

148 ATG TTT CAA CGC ATC GGA TTT CCC GGT GTA ACG AAT TTT CAA Met Phe Gln Arg Ile Gly Phe Pro Gly Val Thr Asn Phe Gln

190 GTG CTT CTT GCA TTA GCA AGT TTG ATC CCG ACT CCT GCG AGT Val Leu Leu Ala Leu Ala Ser Leu Ile Pro Thr Pro Ala Ser

232 CGG GAT TTT TTT CGC CTG CCG CTA ACG GTT GGC TTC ACT GGC Arg Asp Phe Phe Arg Leu Pro Leu Thr Val Gly Phe Thr Gly

274 GCT GAA ATC GTG AAT ATC GAG TTC GAA TGC CTC CGC CAG CTC Ala Glu Ile Val Asn Ile Glu Phe Glu Cys Leu Arg Gin Leu

316 ACG CCA GGT ATG TGA CCCGCGGCCATCGATGCTGGCGCGCTGGCGCGCTG Thr Pro Gly Met

366 CGGGTCGTCCAGCGTGCGATGGACTTCGCTTTCGCTGATC

Fig. 4. Nucleotide sequence of the region containing the $r c s B$ locus carried by pLV215 and the predicted amino acid sequence of a possible rcs protein. A putative Shine-Dalgarno sequence and a possible -10 promoter sequence are shown as referred to in Fig. 3.

$<30^{\circ} \mathrm{C}$. Two of these insertionally inactivated clones, designated pLV216 and pLV217, were subsequently subjected to analysis in minicells.

\section{Minicell analysis of plasmid DNA}

Minicells were utilized to determine the nature of any proteins specified by the recombinant plasmids pLV213 and pLV215. These plasmids were transferred to the minicell-producing $E$. coli strain DS410 and plasmid-encoded protein synthesis was examined in purified minicells. Four proteins with apparent molecular masses of $17,19,23$ and $40 \mathrm{kDa}$ were shown to be expressed by pLV213 in addition to the polypeptides encoded by the vector. Examination of protein synthesis in derivatives in which the putative rcs gene had been inactivated by insertion of DNA fragments revealed the loss of the $23 \mathrm{kDa}$ polypeptide species (Fig. 5). This protein has a molecular mass equivalent to a polypeptide translated from the predicted open reading frame of the sequenced rcs gene in pLV213. The remaining polypeptides specified by the insert probably represent read-through translation products from vector sequences. The cloned DNA in pLV215 could potentially specify a polypeptide of approximately $7000 \mathrm{Da}$. However, this recombinant plasmid did not appear to specify any proteins other than those attributable to the vector itself.

\section{DISCUSSION}

Cloning of total DNA from $K$. aerogenes $\mathrm{K} 21 \mathrm{~b}$ using the plasmid vector pLV59 has allowed the isolation of $E$. coli clones expressing a mucoid phenotype. The clones were of two types, able to express a mucoid phenotype at $\leqslant 30^{\circ} \mathrm{C}$ or at all growth temperatures. We have found that such clones produce $E$. coli $\mathrm{M}$ antigen (colanic acid) rather than $\mathrm{K} 21$ b polysaccharide. Additionally, a supposed $E$. coli transconjugant that had been mated with $K$. aerogenes $\mathrm{K} 21$ (Barr, 1981) was shown to be producing colanic acid rather than Klebsiella K21 polysaccharide. These findings indicate that the presence of certain heterologous DNA segments may induce the synthesis of the colanic acid polysaccharide in $E$. coli and explain the apparent in vivo transfer to $E$. coli of the ability to elicit K21 or structurally related capsular antigens. Mucoid E. coli clones bearing Klebsiella DNA sequences are not sensitive to the SOS-inducing agent MMS and thus do not appear to have a Lon- phenotype. This would suggest that the genes we have cloned do not induce mucoidy because they specify a defective Lon analogue. However, the regulation of 


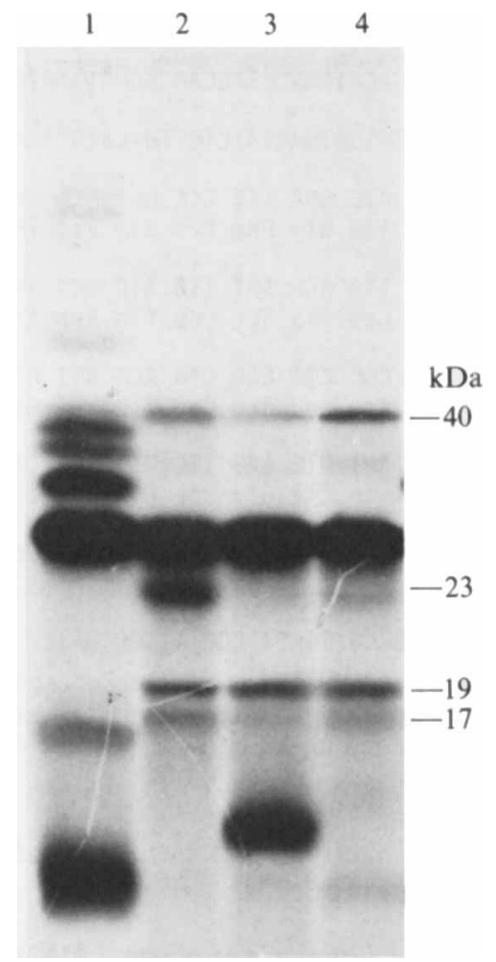

Fig. 5. Autoradiogram of SDS-PAGE of proteins obtained from minicells carrying rcs genes. Minicells were isolated from $E$. coli DS410 carrying pLV59 (track 1), pLV213 (track 2), pLV216 (track 3) and pLV217 (track 4). The 'large' polypeptide band specified by pLV216 but not by pLV21 7 is probably a $\lambda$ protein.

colanic acid synthesis in $E$. coli is complex and other regulatory genes, notably capS and capT, have been described (Markovitz, 1977). Mutations in these gene loci result in the production of large amounts of colanic acid in $E$. coli but do not confer the other phenotypes of lon mutants. More recently, Trisler \& Gottesman (1984) isolated and characterized a number of $E$. coli genes necessary for the synthesis of colanic acid. Mud cps::lac fusions were used to identify three regulatory genes in the $E$. coli chromosome for synthesis of this polysaccharide (Gottesman et al., 1985). These regulatory genes only effect over-production of colanic acid and do not show other Lon- phenotypes. Two of these $E$. coli genes, designated $r \operatorname{cs} A$ and $r c s B$, act as positive regulators of colanic acid biosynthesis. The lon gene product is presumed to regulate capsule synthesis indirectly by regulating the availability of one of the positive regulators. In addition, the $E$. coli $\operatorname{rcs} A$ gene when cloned on a multicopy plasmid induces mucoidy in $l^{+} n^{+}$cells (Gottesman et al., 1985). The cloned fragment of the Klebsiella chromosome carried by pLV212 also produces this effect. This Klebsiella DNA was divisible into two regions, one specified in pLV213 and the other in pLV215. The Klebsiella DNA in pLV213 encodes a single polypeptide of $23 \mathrm{kDa}$, expression of which in E. coli results in mucoidy at temperatures of $30^{\circ} \mathrm{C}$ or below. Disruption of the large open reading frame in pLV213 results in simultaneous loss of this protein and the ability to induce colanic acid biosynthesis. The production of this capsular polysaccharide seems to require the elevated synthesis of a number of different $E$. coli enzymes, including phosphomannose isomerase, UDP-glucose pyrophosphorylase and galactose epimerase (Trisler \& Gottesman, 1984). Therefore it seems unlikely that the $23 \mathrm{kDa}$ polypeptide possesses an enzymic activity that relieves a single deficiency in the biosynthesis of colanic acid. It seems more reasonable to suppose that this protein is the product of a Klebsiella gene, which we have called $\operatorname{rcs} A$, that is capable of regulating the colanic acid regulon. Capsular polysaccharide 
synthesis results at all growth temperatures if the dosage of this Klebsiella rcsA is increased. This effect could be explained if the protein specified by the $\operatorname{rcs} A$ gene is actively competing with a repressor of colanic acid synthesis, such as Lon protease, and if this repressor were to be less readily available at lower growth temperatures. There is some evidence to support this notion as synthesis of colanic acid in E. coli is favoured at low growth temperatures (Markovitz, 1977) and lon strains show less cps: :lac expression at $39^{\circ} \mathrm{C}$ than at $30^{\circ} \mathrm{C}$ (Gottesman et al., 1985). However, the $\operatorname{rcs} A$ gene specified by pLV213 is present as only a single copy in pLV212 but this recombinant is able to induce the mucoid phenotype at all growth temperatures. A second locus that we have designated $r \operatorname{cs} B$ carried by the Klebsiella DNA in pLV212 and isolated in pLV215 is additionally required to give a mucoid phenotype in $E$. coli at $37^{\circ} \mathrm{C}$. The presence of pLV215 alone in $E$. coli does not result in mucoidy at any growth temperature. The cloned DNA in pLV215 does not appear to specify a protein. Moreover, it is possible that this DNA may preferentially bind and thus decrease the availability of a repressor such as Lon. Lon protein is known to exhibit DNA-binding activity (Zehnbauer et al., 1981) although specific DNAbinding sequences have not been identified. Our results are perhaps best explained if the protein specified by the Klebsiella $\operatorname{rcs} A$ gene acts fortuitously or otherwise as a positive regulator of colanic acid synthesis and that activity of this regulatory polypeptide is subject in turn to regulation by Lon protease. If this hypothesis were correct then increasing the dosage of lon should prevent the activation of colanic acid synthesis by the cloned Klebsiella genes.

DNA sequences homologous to the $r c s A$ and $r c s B$ genes from $K$. aerogenes $\mathrm{K} 21 \mathrm{~b}$ were found to be present in all serotypes of klebsiellae so far tested, including those of serotypes K2, K12, K36 and K43. Furthermore, additional rcs genes that show no homology to $r \operatorname{cs} A$ and $r \operatorname{cs} B$ can be detected in cosmid gene libraries of the $K$. aerogenes genome (unpublished observations). Neither $\operatorname{rcs} A$ nor $\operatorname{rcs} B$ is capable of inducing colanic acid biosynthesis when returned to $K$. aerogenes. However, their possible role in the regulation of serospecific Klebsiella capsular polysaccharides is currently under investigation.

This work was supported by an MRC project grant to J.R.S. and C.A.H. We are grateful to F. Ørskov and I. Ørskov for serotyping of clones.

\section{REFERENCES}

APPlEYARD, R. K. (1954). Segregation of new lysogenic types during growth of a doubly lysogenic strain derived from Escherichia coli K12. Genetics 39, 440-445.

BARR, J. G. (1981). Spontaneous loss and transfer of plasmid-mediated K21 antigen synthesis in Klebsiella pneumoniae. Journal of Clinical Pathology 34, 434-438.

Bolivar, R., Rodriguez, R. L., Greene, P. J., Betlach, M. C., Heynecker, H. L. \& Boyer, H. W. (1977). Construction and characterisation of new cloning vehicles. II. A multipurpose cloning system. Gene 2, 95-113.

Casewell, M. W. (1972). Experiences of the use of commercial antisera for the typing of Klebsiella species. Journal of Clinical Pathology 25, 734-737.

Choy, Y. M. \& Dutton, G. G. S. (1973). The structure of the capsular polysaccharide from Klebsiella Ktype 21. Canadian Journal of Chemistry 51, 198-207.

Chung, C. H., Waxman, L. \& Goldberg, A. L. (1983). Studies of the protein encoded by the lon mutation CapR9 in Escherichia coli: a labile form of the ATP-dependent protease $\mathrm{La}$ that inhibits the wild-type protease. Journal of Biological Chemistry 258, 215-221

GAREGG, P. J., LINDBERG, B., ONN, T. \& SUTHERLAND,
I. W. (1971). Comparative structural studies on the M-antigen from Salmonella typhimurium, Escherichia coli and Aerobacter cloacae. Acta chemica scandinavica 25, 2103-2108.

Gottesman, S., Trisler, P. \& Torres-Cabassa, A. 1985). Regulation of capsular polysacchanje synthesis in Escherichia coli K12: characterisation of three regulatory genes. Journal of Bacteriology 162, 11111119.

Halliwell, R. A. \& Sherratt, D. J. (1976). Isolation and characterisation of ColE2 plasmid mutants unable to kill colicin sensitive cells. Molecular and General Genetics 146, 239-245.

HaNAHAN, D. (1983). Studies on transformation of Escherichia coli with plasmids. Journal of Molecular Biology 166, 557-580.

HenRIKSEN, S. D. (1954). Studies on the Klebsiella group (Kauffman). IV. Cross-reactions of Klebsiella types $8,11,21,26$ and 35 , and the M-antigen of Escherichia coli. Acta pathologica et microbiologica scandinavica 34, 271-275.

Howard-Flanders, P., Simson, E. \& Theriot, L. (1964). A locus that controls filament formation and sensitivity to radiation in Escherichia coli K12. Genetics 49, 237-246.

Humphreys, G. O., Willshaw, G. A. \& Anderson, 
E. S. (1975). A simple method for the preparation of large quantities of pure plasmid DNA. Biochimica et biophysica acta $383,457-463$.

LAEMMLI, U. K. (1970). Cleavage of structural proteins during the assembly of the head of bacteriophage T4. Nature, London 227, 680-685.

MARKovitZ, A. (1977). Genetics and regulation of bacterial capsular polysaccharide biosynthesis and radiation sensitivity. In Surface Carbohydrates of the Prokaryotic Cell, pp. 415-426. Edited by I. W. Sutherland. London: Academic Press.

MARMUR, J. (1961). A procedure for the isolation of deoxyribonucleic acid from micro-organisms. Journal of Molecular Biology 3, 208-218.

Meers, P. D., Ayliffe, G. A. J., Emmerson, A. M., Leigh, D. A., Mayon-White, R. T., Mackintosh, C. A. \& Strange, J. L. (1981). National Survey of Infection in Hospitals. Journal of Hospital Infection 2 , supplement, 1-39.

Messing, J. \& VieIRA, J. (1982). A new pair of M13 vectors for selecting either DNA strand of doubledigest restriction fragments. Gene 19, 269-276.

Morgan, M. E. l., HaRT, C. A. \& COOKE, R. W. I. (1984). Klebsiella infection in a neonatal intensive care unit: role of bacteriological surveillance. Journal of Hospital Infection 5, 377-385.

Nimmich, W. (1968). Zur Isolierung und Qualitativen Bausteinanalyse der K-antigene von Klebsiellen. Zeitschrift für medizinische Mikrobiologie und Immunologie 154, 117-131.

O'CoNnor, C. D. \& Humphreys, G. O. (1982). Expression of the EcoRI restriction modification system and the construction of positive-selection cloning vectors. Gene 20, 217-227.

Palfreyman, J. M. (1978). Klebsiella serotyping by counter-current immunoelectrophoresis. Journal of Hygiene 81, 219-225.

SAunders, J. R., Docherty, A. \& Humphreys, G. O. (1984). Transformation of bacteria by plasmid DNA. Methods in Microbiology 17, 61-95.
Schoemaker, J. M. \& Markovitz, A. (1981). Identification of the gene lon (capR) product as a 94kilodalton polypeptide by cloning and deletion analysis. Journal of Bacteriology 147, 46-56.

SoUTHERN, E. M. (1975). Detection of specific sequences among DNA fragments separated by gel electrophoresis. Journal of Molecular Biology 98, 303-518.

Stoker, N. G., Fairweather, N. F. \& Spratt, B. G. (1982). Versatile low-copy-number plasmid vectors for cloning in Escherichia coli. Gene 18, 335-341.

DE la Torre, M. G., Romero-Vivos, J., MartinezBeltran, J., Guerrero, A., Meseguer, M. \& BouzA, E. (1985). Klebsiella bacteraemia : an analysis of 100 episodes. Reviews of Infectious Diseases 7 , 143-150.

TRISLER, P. \& GotTesman, S. (1984). lon transcriptional regulation of genes necessary for capsular polysaccharide synthesis in Escherichia coli K12. Journal of Bacteriology 160, 184-191.

Walker, J., Dean, P. \& SAunders, J. R. (1986). Identification and characterisation of PmaCI, an endonuclease of novel specificity from Pseudomonas maltophila. Nucleic Acids Research 14, 1293-1301.

WALKer, J. R., USSERY, C. C. \& AlleN, T. S. (1973). Bacterial cell division regulation: lysogenisation of conditional cell division mutants of Escherichia coli by bacteriophage lambda. Journal of Bacteriology 111, 1326-1332.

Wilkinson, J. F., Dudman, W. F. \& Aspinall, G. D. (1955). The extracellular polysaccharide of Aerobacter aerogenes A3 (S1) (Klebsiella Type 54). Biochemical Journal 59, 446-451.

Zehnbauer, B. A., Foley, E. C., Henderson, G. W. \& MARKOVITZ, A. (1981). Identification and purifcation of the $\mathrm{Lon}^{+}\left(\mathrm{CapR}^{+}\right)$gene product, a DNA binding protein. Proceedings of the National Academy of Sciences of the United States of America 78, 20432047. 